\title{
The road from Doha to Hong Kong in the WTO agricultural negotiations: a developing country perspective
}

\author{
Alan Matthews \\ Trinity College Dublin, Dublin, Ireland
}

\section{Summary}

Developing countries have both offensive and defensive interests in the Doha Round of WTO trade negotiations. This paper discusses the extent to which these interests have been addressed in the July 2004 Framework Agreement and in the subsequent negotiations. Many of the key demands of developing countries appear to have been accepted in principle in the Agreement, but the lack of specific details on how most of these principles will be operationalised makes it hard to evaluate their real significance. Progress is needed on the development dimension of the negotiations if the Hong Kong Ministerial Council meeting is to succeed.

Keywords: WTO Doha Round, agriculture, developing countries, special and differential treatment

JEL classification: F13, Q17

\section{Introduction}

From the outset, it was recognised that the Doha Round of WTO trade negotiations had to be a development round. Paragraph 2 of the 2001 Doha Ministerial Declaration acknowledges that 'The majority of WTO Members are developing countries. We seek to place their needs and interests at the heart of the Work Programme adopted in this Declaration' (WT/ MIN(01)/DEC/W/1). ${ }^{1}$ Although developing countries have interests to promote in all of the areas under negotiation, they have repeatedly made it clear that, for them, agriculture is the key issue that will determine whether or not they sign up to a deal. The Chairman of the Special Committee on Agriculture, Mr Tim Groser, noted in his status report to the Committee in June 2005 that agriculture is critical to ensuring that there is a 'development return' from the Round, for two broad reasons (TN/AG/19). The first reason is because many developing countries and least developed countries (LDCs) see potential opportunities once the large trade distortions in world agriculture

1 The WTO documents cited in the text are available on the WTO website, at www.wto.org. 
markets are either eliminated or substantially reduced. ${ }^{2}$ The second reason is because many developing countries, and particularly LDCs, have deeply vulnerable people who depend on agriculture. There is a need to ensure that integrating the agricultural sectors of these countries into any emerging reform framework takes their interests into account. These concerns shape 50 the 'offensive' and 'defensive' interests, respectively, of developing countries in these negotiations.

The negotiations to reach a further agreement on agriculture by the Hong Kong Ministerial Council, meeting in December 2005, are taking place on the basis of the Framework to Establish Modalities in Agriculture attached 55 to the Doha Work Programme agreed by the WTO General Council on 1 August 2005 (WT/L/579), generally known as the July Framework Agreement (FA) or 'July Package'. The purpose of this paper is to assess the extent to which the measures and commitments in the FA meet developing country demands, and to assess the prospects for consensus on the modalities of an 60 agriculture agreement in Hong Kong given what is known about countries' negotiating offers to date. The next section of the paper identifies the main developing country negotiating groups and the interests that they represent. Subsequent sections discuss the extent to which these interests are being addressed in the different negotiating pillars of market access, export compe- 65 tition and domestic support, as well as the particular case of cotton. The final section summarises the main issues on which progress must be made if the agricultural dossier in the Doha Development Round is to produce an outcome that satisfies developing countries.

\section{Developing country demands in the Doha Round negotiations}

A key difference between the Uruguay Round and the Doha Round negotiations on agriculture is the active participation of developing countries. 75 For example, Brazil and India are members of the 'new Quad' group with the USA and the EU. Together with Australia, they are known as the Five Interested Parties (FIPs), and have been attempting to play a leadership role in forging common positions on which the entire WTO membership might agree. Beyond the greater participation of individual developing countries, 80 the most significant change in negotiation dynamics has been the formation of more-or-less formal alliances among developing countries around specific issues. The most significant is the G20, established on 20 August 2003 in the final stages of the preparations for the Cancún Ministerial Conference. The formation of the group was catalysed by the pre-conference draft of the agri- 85 culture modalities circulated by conference chairman Luis Ernesto Debrez,

2 WTO rules allow exceptional treatment for two groups of countries. Developing countries are those countries that designate themselves as developing country members of the WTO and they currently account for about two-thirds of the membership. LDCs are countries that have been designated as such by the UN. There are currently 50 such countries, of which 32 are WTO members. 
which was perceived as reflecting too closely proposals circulated earlier by the USA and the EU. The Group circulated a counter-proposal for the negotiations on agriculture, which remains its central platform (WT/ MIN(03)/W/6). Its main objective is to achieve an ambitious outcome in the market access negotiations, with greater access to developed country agricultural markets in particular, while defending the interests of developing countries. The G33, coordinated by Indonesia, was also established on the eve of the Cancún Conference on 9 September 2003. Initially known as the 'SP and SSM Alliance', its main concern is to ensure that the issues of food security, rural livelihoods and rural development become an integral part of the negotiations. Its negotiating objective is to have the concepts of the Special Safeguard Mechanism (SSM) and Special Products (SPs) embodied in the modalities of the WTO agriculture negotiations. A further grouping is the G90, an alliance of African, Caribbean and Pacific (ACP) and African Union states and LDCs. The G90 Platform on the Doha Work Programme notes that G90 countries are essentially weak and vulnerable economies, largely dependent on long-standing preferences for their economic development and require effective, binding and meaningful Special and Differential Treatment (SDT) in all areas of the WTO Work Programme. ${ }^{3}$ Members of the group do not necessarily share all positions in the negotiations, but they are bound by a common concern about preference erosion. Finally, the Cairns Group consists of agricultural exporting countries with both developed and developing country members and with the objective of seeking an ambitious outcome in terms of market access in the Doha Round negotiations. ${ }^{4}$

The existence of these different groups, despite their overlapping membership, underlines the fact that not all developing countries necessarily share the same interests in the negotiations. None the less, developing countries have maintained a remarkable unity around three issues, as follows.

(i) Offensive demands for a high level of ambition in disciplines in the three main pillars under negotiation-market access, export competition and domestic subsidies. This includes extension of duty-free and quota-free access for LDCs, as well as full liberalisation of access for tropical products. Support for this demand is moderated by the concerns of preference recipients about the impact of reduced tariffs on the value of their preferences.

(ii) A defensive interest in retaining the maximum policy space to take account of particular vulnerabilities, particularly to address food security, livelihood security and rural development concerns. This explains the emphasis on special and differential treatment in the negotiations, and the proposal for a Development Box (Matthews, 2005). SDT has been

3 The G90 Platform is available at http://www.acp.int/en/archives/G-90_en.html.

4 The membership of the various groups is described in the WTO Secretariat document 'WTO Agriculture Negotiations: The issues, and where we are now', which is updated regularly on the WTO website. 
interpreted as proportional concessions in the three pillars, a demand for recognition of Special Products and introduction of a Special Safeguard Mechanism, as well as other rule changes facilitating developing countries' pursuit of their food and agricultural policy objectives. Support for this demand is tempered by concerns of the (mainly Latin 140 American) agricultural exporting countries that other developing countries should not have carte blanche to protect their agricultural sectors and thus hamper South-South trade.

(iii) Recognition of cotton as a special case. This issue was raised by four West African cotton exporters, who claimed just before the Cancún Ministerial Meeting that heavy support for cotton producers in developed countries was leading to depressed world market prices. They called for the abolition of cotton subsidies and, in the meantime, for financial compensation.

\section{Market access-how ambitious will market opening be?}

By common consent, the market access pillar is proving the most difficult to negotiate. The FA set out a number of agreed principles to guide the negotiations. These were: a high level of ambition in the overall outcome; that highest tariffs would be reduced the most; that a tiered approach would be used; that special treatment would apply to sensitive products; and that SDT would apply to developing countries. However, no numbers were provided to show how these principles would be made operational (Anania and Bureau, 2005).

Since then, a number of proposals have been made regarding the structure of an appropriate formula, including submissions by the G20, Canada, Australia, the USA and the EU. In the absence of numbers, the likely outcomes from these proposals cannot be compared. The G20 proposal can be seen as forging a middle ground between the radical liberalisers (such as the USA 165 and the Cairns Group, which advocated the use of the Swiss formula with a low tariff cap) and the reluctant liberalisers (such as the G10 and the EU, which favoured the Uruguay Round approach). The outcomes are further complicated by the provision in the FA concerning sensitive products. The debate on sensitive products is linked to the degree of flexibility included in the tariff 170 reduction formula. To ensure a significant degree of market opening, it is accepted that tariff rate quotas (TRQs) would have to be increased to compensate for a lower tariff reduction. However, there is disagreement about whether the tariff reduction-TRQ expansion combination should be related to the main formula for tariff reduction or not.

Other issues on the market access agenda of interest to developing countries can be briefly mentioned. Paragraph 43 of the FA refers to an 'overdue' and 'long-standing commitment' for the 'fullest liberalisation' for tropical products in importing developed countries. Many Latin American countries stress this demand for full liberalisation of tropical products and crops pro- 180 duced as alternatives to narcotics. For other countries, such as the EU and 
the G90, this demand threatens long-standing preferences, for example, in sugar and bananas. Tariff escalation also remains a concern of developing countries. The FA (paragraph 36) states that 'tariff escalation will be addressed through a formula to be agreed'. For the LDCs, there is a commitment that developed members, and developing country members in a position to do so, should provide duty-free and quota-free market access for products originating from least-developed countries, although whether this is more than exhortatory remains to be seen.

\section{Market access-special and differential treatment}

\subsection{Tariff reduction formulae}

As noted, many developing countries want to retain the maximum amount of policy space to pursue domestic food and agricultural policy objectives. Hence the emphasis placed on SDT. Indeed, LDCs have been exempted from any requirement to open their markets beyond their existing commitments and the EU has proposed that this treatment be extended to other vulnerable countries in a similar situation, essentially the G90, although this would imply the creation of a further category of developing country members in the WTO (EU Commission, 2004). An important issue for other developing countries is how to reconcile a formula approach to tariff reductions with special and differential treatment. SDT in the Uruguay Round (UR) meant that commitments by developing countries averaged two-thirds of those undertaken by developed countries. If this is to be repeated in the Doha Round, the question is whether this commitment is built into the formula to be used or into the objective to be achieved. Application of the same formula can lead to different outcomes depending on the initial structure of tariffs. There are considerable differences between the structure of bound tariffs within both developed and developing countries, as well between developed and developing countries. ${ }^{5}$ Using a tiered approach with the deliberate aim of harmonising tariffs, there will be a wide dispersion in the average tariff reduction achieved even among developed countries. A general objective that developing countries should reduce their tariffs by an average of two-thirds of the developed country average reduction is going to be hard to achieve in terms of a specific formula.

The SDT objective has been built into the formula itself in various ways in each of the proposals made to date. The EU proposal builds in two-thirds proportionality by both increasing the limits for each tier by 50 per cent and decreasing the average cut required in each tier by one-third. The G20 proposal has a smaller number of tiers for developing countries and also a smaller reduction coefficient within each tier, but no figure is mentioned. The US proposal is less precise as regards how SDT would be implemented under its formula. 
The difficulty arises where developing countries start with very high and uniform bound tariffs initially. Many developing countries are in this position because they opted for ceiling bindings in the UR. ${ }^{6}$ Although SDT in the formula would mean that developing countries would be treated more leniently than a developed country with the same tariff structure, the differences 230 in the initial tariff structures could mean that, in practice, the average cuts to be undertaken by many developing countries would be considerably greater than the average cuts undertaken by developed countries. Developing countries often apply tariffs well below their bound rates, so larger reductions in their bound rates would not necessarily translate into larger reductions in 235 applied rates. However, the negotiations are about bound rates, so a solution needs to be found.

Even the Canadian proposal for mechanical thresholds, where the band thresholds would be determined by dividing the tariffs of each country into three (or more) equal tiers, would not address this issue because of the uni- 240 formity of the tariff structures. Kenya, on behalf of the African Group, has suggested three options to deal with this problem: countries with ceiling bindings would be subject to an overall tariff reduction only; they could spread their tariff lines across the various tiers, on the basis of their own assessment of sensitivities; or there could be agreement that no developing country 245 with ceiling bindings would be placed in the tier for the highest reductions, irrespective of the agreed thresholds.

Interpreting the actual outcome of any formula for an individual developing country is complicated, as for developed countries, by the number and treatment of sensitive products that will be allowed. According to the FA (para- 250 graph 39), developing countries will benefit from special and differential treatment (SDT) in the designation and treatment of sensitive products. This would imply that these countries may designate more sensitive products and undertake lesser commitments with respect to tariff reductions and tariff rate quota expansion than may otherwise be required.

\subsection{Special products}

In addition to being able to designate sensitive products, the FA foresees (paragraph 41) that 'Developing country Members will have the flexibility 260 to designate an appropriate number of products as Special Products, based on criteria of food security, livelihood security and rural development needs. These products will be eligible for more flexible treatment.' This represents a significant gain for proponents of SPs. It guarantees that developing countries will have access to this flexibility in a revised agreement on agricul- 265 ture and it clarifies that the basic criteria that should guide the designation of

6 The normal method of establishing the bound tariff equivalent of non-tariff barriers in the UR agriculture agreement was through tariffication, setting bound tariffs at a level equivalent to the protection provided by the non-tariff barriers. Developing countries exceptionally could opt to offer a ceiling binding on products not previously bound, which could be any level of protection they deemed appropriate. 
SPs will be food and livelihood security, and rural development needs. On the other hand, the text establishes limits to the possible scope of SPs, for instance, by requiring that only an appropriate number of products could be so designated. How this number should be determined is left to further negotiation, as is the treatment of SPs. The G33 demands self-designation of the number of tariff lines to be considered as SPs, and that SPs should be exempted from any reduction commitments or requirements for TRQ expansion. Some countries would like to minimise the number of SPs and feel there should be common designation criteria across all developing countries. At its meeting in Jakarta in June 2005, the G33 offered to come up with indicators based on food security, livelihood security, and rural development needs. This offer was welcomed by other members as a move away from an apparent blank cheque for developing countries to pick their SPs. However, developed countries continue to insist that SPs should require at least some tariff reductions.

\subsection{Special safeguard mechanism}

Developing countries have worried that trade liberalisation could leave them vulnerable to import surges or a price collapse on world markets, in a situation where they have very limited ability to protect producers through purely internal measures. We have seen that the G33 was formed to defend the need for a special safeguard mechanism (SSM) for developing countries, along with the concept of SPs. Paragraph 42 of the FA states that 'a special safeguard mechanism (SSM) will be established for use by developing country Members.' Although this represents substantial progress by developing countries, no guidance is given as to the design of this mechanism.

The G33 has argued that an SSM should have the following features: the safeguard measure should be automatically triggered; it should be available to all agricultural products; both price- and volume-triggered safeguards should be considered; both additional duties and quantitative restrictions should be available as remedies; and the mechanism should be simple, effective and easy to implement. On the other hand, developed countries (and some developing countries) have argued for restricted product coverage and more limited triggers and remedies.

The disagreements in relation to product eligibility revolve around a number of issues: whether to use multilaterally agreed, development-related criteria or to allow self-designation; whether to limit SSM use to a specific number of tariff lines or allow access by all tariff lines; and whether access to the SSM should be related to the depth of the tariff cuts and/or the final level of the bound tariff. Developed countries suggest that the SSM should apply only to staple food products or products necessary for food security that are produced in the developing country concerned, and to products that already have low tariffs, in order to facilitate the overall liberalisation process.

As the existing Special Safeguard (SSG) allows both price and volume triggers, it is not surprising that SSM proponents have sought the same flexibility. 
Developed countries have argued that the purpose of the SSM is to deal with import surges, and thus a volume trigger should be sufficient. Academic commentators (e.g. Valdés and Foster, 2005) have argued in favour of price triggers. Volume triggers require up-to-date reliable information, which may be difficult to provide in developing countries. A shortfall in domestic pro- 320 duction, rather than a change in external circumstances, could also spring a volume trigger (although developing countries are not required to use the special safeguard and may well choose not to in such circumstances). Also with respect to remedies, developed countries are reluctant to countenance the use of quantitative limits, arguing that augmenting the tariff is more in 325 keeping with WTO norms.

\subsection{Preference erosion}

Preference erosion has emerged as one of the important issues that need to be 330 addressed in the agricultural negotiations. Many developing countries, and particularly the LDCs, benefit from access to developed country markets on preferential terms. As most-favoured-nation (MFN) tariffs are cut, the value of these preferences is reduced. Paragraph 44 of the Framework Agreement on agriculture states that: "The importance of long-standing preferences is fully recognised. The issue of preference erosion will be addressed. For the further consideration in this regard, paragraph 16 and other relevant provisions of TN/AG/W/1/Rev.1 will be used as a reference.'

The cross-reference in this paragraph is to proposals to cope with preference erosion in the revised Harbinson draft framework presented in March 2003.

(i) In implementing their tariff reduction commitments, participants undertake to maintain, to the maximum extent technically feasible, the nominal margins of tariff preferences and other terms and conditions of preferential arrangements they accord to their developing trading 345 partners.

(ii) As an exceptional measure, tariff reductions affecting long-standing preferences in respect of products that are of vital export importance for developing country beneficiaries of such schemes may be implemented in equal annual instalments over a period of [eight] instead of [five] 350 years by the preference-granting participants concerned, with the first instalment being deferred to the beginning of the [third] year of the implementation period that would otherwise be applicable. The products concerned shall account for at least [20] per cent of the total merchandise exports of any beneficiary concerned on a three-year average out of the 355 most recent five-year period for which data are available. In addition, any in-quota duties for these products shall be eliminated.

(iii) The preference-providing members shall undertake targeted technical assistance programmes and other measures, as appropriate, to support preference-receiving countries in efforts to diversify their economies 360 and exports. 
These proposals encompass the conflicting views on how best to address preference erosion, whether through trade policy measures that either slow down the pace of preference erosion or compensate for it, or through complementary financial measures that assist countries to cope with its adverse consequences. Maintaining the nominal value of preferences is clearly not possible when the preferential tariff is already zero. The debates on preference-maintaining trade policy measures and on sensitive products overlap because the same products tend to be involved. The EU, with support from the G90, sees a justification for sensitive products in order to moderate tariff reductions where preferences exist. The USA and the Cairns Group (including Latin American exporters) are more critical of integrating preference erosion into the modalities, and put more emphasis on expanding market access for products that are of vital export interest to the preference beneficiaries.

The G90 have pushed for a compensation fund that would ensure compensation for losers. There is a precedent in the Decision on Net Food Importing and Least Developed Countries, which promised to maintain food aid flows and to increase technical assistance to countries adversely affected by higher world market food prices as a result of the Uruguay Round agriculture agreement. Developed countries have argued that this is a problem for the IMF and the World Bank. The IMF in March 2004 established the Trade Integration Mechanism designed to 'mitigate concerns that implementation of WTO agreements might give rise to temporary balance of payments shortfalls'. It provides funding, within existing facilities, to offset expected losses from preference erosion on the usual IMF terms and conditions. The World Bank has come out against a special mechanism, arguing that compensation should be addressed as part of the general support for countries' development. This would allow general developmental criteria be applied to assess needs and ensure that additional funds would be well used.

\section{Export competition}

All major developing country groups have demanded the elimination of export subsidies. The FA contains conditional agreement on this. As identified by the Chairman, the remaining issues are to flesh out the parallel commitments in export credits, export state trading enterprises (STEs) and food aid, as well as to define the 'credible end date' for the elimination of export subsidies and the implementation path.

Because few developing countries are entitled to use export subsidies, they have few defensive interests in this pillar. However, developing countries are likely to continue to want to make use of price intervention schemes as part of their agricultural policy. Experience in Europe shows how difficult it can be to keep support prices in line with market trends. Where countries build up stocks as a result of price stabilisation or price guarantee policies, the issue of how to dispose of surpluses will arise. The FA allows developing countries to continue to provide (for a period to be negotiated) export subsidies for transport 
and marketing as allowed under Article 9.4 of the existing Agreement on Agriculture. Some developing countries have proposed expanding the types of export subsidies developing countries are allowed to use under Article 9.4. They want to see exemptions along the lines of Article 27 and Annex 7 of the Subsidies Agreement (which allow developing countries with a per 410 capita GNP less than $\$ 1,000$ to provide export subsidies, as well as longer phase-out periods for other developing countries).

Other developing countries are concerned that the disciplines on export competition measures, including export credits and food aid, could have negative implications for meeting humanitarian and development needs. The FA 415 states that such disciplines will provide for differential treatment in favour of the least developed and net food importing countries, without compromising the objective of eliminating their trade-distorting effects. It refers to the Marrakesh Decision in favour of these countries to maintain food aid levels, but without acknowledging the structural flaws in the Decision that have pre- 420 vented its implementation. There is a common desire to ensure that food aid in emergencies is not compromised, but some of the other disciplines proposed in this area (such as requiring all food aid to be given in grant form) could have negative consequences on the overall flow of food aid.

Some developing countries also have interests in the STE debate. Although 425 state marketing boards are now much less prevalent in developing countries than used to be the case, disciplines on the financing of STEs, and on the use of monopoly export powers, will affect some countries. Kenya has proposed that developing country STEs be exempt from disciplines because of the role they play in development. The FA proposes that 'STEs in developing 430 country Members which enjoy special privileges to preserve domestic consumer price stability and to ensure food security will receive special consideration for maintaining monopoly status'.

\section{Domestic support}

Few developing countries have entitlements to provide trade-distorting domestic support beyond de minimis levels. Thus their interest in this pillar of the negotiations is primarily offensive. The G20 has made the most detailed proposal for reductions in aggregate measure of support (AMS) and in overall 440 trade-distorting domestic support among the developing country groups. The FA (paragraph 6) recognises that 'Special and differential treatment remains an integral component of domestic support. Modalities to be developed will include longer implementation periods and lower reduction coefficients for all types of trade-distorting domestic support and continued access to the pro- 445 visions under Article 6.2.' In addition, three further issues have been pursued by developing countries.

While calling for reductions in both product specific and non-product specific de minimis support provided by developed countries, the G20 has proposed that developing countries with no AMS entitlements should be exempt 450 from any reduction requirement in their allowable de minimis levels (these are 
currently twice the levels allowed for developed countries). The Framework Agreement goes some way to meeting this demand. Paragraph 11 states that 'Developing countries that allocate almost all de minimis programmes for subsistence and resource-poor farmers will be exempt' from any reductions in de minimis levels.

Developing countries have also been the main proponents of stricter criteria for blue box and green box payments in order to prevent box-shifting. On the other hand, they would like to see more of the support measures undertaken in developing countries qualify for green box status under Article 6.2 of the existing Agreement. Developed countries are likely to concede to this latter demand, possibly in return for agreement to leave the existing criteria for green box measures unchanged.

\section{Cotton}

Cotton became a specific issue in the Doha Round when four West African countries-the C4 (Benin, Burkina Faso, Chad and Mali)—presented a Sectoral Initiative in Favour of Cotton to the agricultural negotiations in May 2003 (TN/AG/GEN/4) and subsequently to the Cancún Ministerial Conference in August 2003 (WT/MIN(03)/W/2). It called for eliminating all tradedistorting cotton subsidies and border measures, and compensation for the economic losses of African cotton producers while subsidies were phased out. A significant aspect of the proposal was that there should be an accelerated reduction of cotton supports and a date set for their complete elimination. This was justified on the argument that Special Products should not be restricted to defensive measures but should equally be applicable to offensive measures when the export of a product is essential for agricultural development or survival of the rural population in LDCs, as the C4 argued is the case for cotton.

480 Although there was sympathy for the $\mathrm{C} 4$ position, members differed as to whether cotton should be handled as a specific issue or addressed within the agriculture negotiations, leading to deadlock in the negotiations in Cancún. The cotton proponents continued to press their case in the first half of 2004, and there was significant progress in acknowledging their demands in the 485 FA. It states that the cotton issue will be addressed 'ambitiously, expeditiously, and specifically, within the agriculture negotiations'. It created a sub-committee on cotton with both trade and development tracks to review all trade-distorting policies affecting the sector in all three pillars of market access, domestic support, and export competition as well as to monitor coherence between the trade and development aspects.

Reaction from developed countries has been mixed. The EU has proposed that action on cotton should be front-loaded, meaning acting quicker on those parts of an agriculture deal that would apply to cotton. It supports immediate action on the first day that the new agriculture deal comes into force to eliminate tariffs and quotas on cotton products from all countries (not just the least developed); to eliminate export subsidies on cotton; and to substantially 
reduce domestic support. The US position is more reserved. It highlights empirical studies suggesting that the removal of cotton support would have a very limited impact on world market prices, and it points to the many other factors that adversely affect the prices received by West African cotton producers. It argues that their problems can be addressed by an ambi- 500 tious outcome under the three pillars in the agriculture negotiations, and has warned that seeking an early harvest only undermines the momentum of the negotiations and threatens the cross-cutting approach. On the other hand, it has not ruled out a sectoral initiative, pointing out that it has supported such initiatives in other products. It rejects the idea of an emergency fund as pro- 505 posed by the $\mathrm{C} 4$, while accepting there could be a role for targeted assistance to help improve competitiveness.

\section{State of play in the agricultural negotiations from a developing country perspective}

The Framework Agreement and subsequent negotiations make clear that many of the key demands of developing countries have been accepted in principle. In terms of their offensive demands, there is conditional agreement to eliminate export subsidies, to seek ambitious reductions in tariffs and domestic support, 515 to support provision of duty-free and quota-free access for LDCs, and to come to an ambitious and expeditious agreement on cotton. In terms of their defensive interests, agreement on less than proportional reciprocity, Special Products and a Special Safeguard Mechanism, as well as recognition of the problem of preference erosion and agreement not to require cuts in de 520 minimis support where this is provided to subsistence and resource-poor farmers, are notable achievements. However, the glass can be seen as halffull or half-empty. The lack of specific details on how most of these principles will be operationalised makes it hard to evaluate their real significance. Developing countries have expressed concern at the sequencing of the negotiations 525 proposed by Groser in his status report in June 2005, in which he argued that the negotiations should initially address the structure of commitments in all the three pillars, leaving the SDT measures to be discussed later. Developing countries have argued that there needs to be simultaneous attention to the 'development dimension' as the talks broaden in the more comprehensive 530 agenda being addressed in the months before the Hong Kong Ministerial.

Many issues remain outstanding, starting with the level of ambition being sought in the market access negotiations. What headline cuts will be agreed, and what will be the scope for flexibility and sensitive products? How can the unbalanced incidence of a tariff reduction formula on countries with 535 high and uniform ceiling bindings be addressed? Will developed countries insist on differentiating between developing countries in the extent of reciprocity sought in market access concessions? Will Special Products be exempt from tariff reductions, and how many will there be? Will access to the Special Safeguard Mechanism be limited, and what triggers and remedies 540 will be allowed? Will there be a parallel to the Uruguay Round Marrakesh 
Declaration to address the concerns of preference recipients over preference erosion? Will there be a separate modality for tropical products to ensure 'fullest liberalisation'? Although the Framework Agreement says that developed countries, and developing countries in a position to do so, should provide duty-free and quota-free access to LDCs, will they do so? The answers to these questions will gradually emerge as the date for the Hong Kong Ministerial draws closer.

\section{Acknowledgements}

This paper is an output of the Policy Coherence project based in the Institute for International Integration Studies at Trinity College Dublin, supported by a research grant from the Advisory Board for Development Cooperation Ireland.

\section{References}

Anania, G. and Bureau, J.C. (2005). The status and prospects of the negotiations on agriculture in the Doha Development Agenda Round. European Review of Agricultural Economics 00: 000-000.

EU Commission (2004). Letter from Pascal Lamy and Franz Fischler to WTO members, 9 May 2004.

Jales, M., Josling, T., Nassar, A. and Tutwiler, A. (2005). Market Access, Trade Policy Issues Paper 2-2005. International Agricultural Trade Research Consortium.

Matthews, A. (2005). Special and differential treatment in the WTO Negotiations. In P. Rainelli (ed.), Les Politiques Agricoles sont-elles Condamnées par la Mondialisation? Paris: Institut français des relations internationales and Academia-Bruylant.

Valdés, A. and Foster, W. (2005). The new SSM: a price floor mechanism for developing countries. Geneva: International Centre for Trade and Sustainable Development.

Corresponding author: Professor Alan Matthews, Department of Economics, Trinity 